\title{
STUDY OF SELECTED PROPERTIES OF THERMALLY SPRAYED COATINGS CONTAINING WC AND WB HARD PARTICLES
}

\author{
Janette BREZINOVÁ*, Anna GUZANOVÁ, Dagmar DRAGANOVSKÁ*, Pavlo O. MARUSCHAK", Mariana LANDOVÁ*
}

\author{
*Faculty of Mechanical Engineering, Department of Mechanical Technology and Materials, \\ Technical University of Košice, Mäsiarska 74, 04001 Košice, Slovakia \\ ${ }^{*}$ Faculty of Computer Technologies, Department of Automation of Technological Processes and Productions, \\ Ternopil Ivan Pul'uj National Technical University, Ruska str., 56, Ternopil, Ukraine \\ janette.brezinova@tuke.sk, anna.guzanova@tuke.sk, dagmar.draganovska@tuke.sk, \\ maruschak.tu.edu@gmail.com, mariana.landova@tuke.sk
}

received 23 February 2016, revised 29 November 2016, accepted 2 December 2016

\begin{abstract}
The paper presents results of research of the essential characteristics of two kinds of advanced coatings applied by HVOF technology. One studied coating: WB-WC-Co (60-30-10\%) contains two types of hard particles (WC and WB), the second coating is ecofriendly alternative to the previously used WC-based coatings, called "green carbides" with the composition WC-FeCrAl (85-15\%). In green carbides coating the heavy metals $(\mathrm{Co}, \mathrm{Ni}, \mathrm{NiCr})$ forming the binding matrix in conventional wear-resistant coatings are replaced by more environmentally friendly matrix based on FeCrAl alloy. On the coatings was carried out: metallographic analysis, measurement of thickness, micro-hardness, adhesion, resistance to thermal cyclic loading and adhesive wear resistance (pin-on-disk test). One thermal cycle consisted of heating the coatings to $600^{\circ} \mathrm{C}$, dwell for 10 minutes, and subsequently cooling on the still air. The number of thermal cycles: 10. The base material was stainless steel AISI 316L, pretreatment prior to application of the coating: blasting with white corundum, application device JP-5000.
\end{abstract}

Key words: Coating, HVOF Technology, Adhesion, Friction Coefficient, Thermal Loading

\section{INTRODUCTION}

The components of production machines in technical practice are stressed by various operating conditions (transmitted forces, pressures, temperature, environment, etc.). By the influence of these diverse effects, in the majority of machines and their components stresses occurs, which causes unwanted damage of the surface (wear, deformation, corrosion, cracks, fractures etc.). To avoid substantial damage of surfaces of machinery components, there have been developed various methods of forming protective layers, resistant to operating conditions. Thermal spraying technology also belongs to such methods. Coatings formed using thermal spraying technology for its high hardness and wear resistance even at higher operating temperatures are often applied in many fields of industry, especially in automotive, aerospace, energy, engineering, manufacturing and mining industry.

Recently, just cermet coatings containing hard WC particles in metallic matrix applied using HVOF (High Velocity Oxygen Fuel) technology was seen as a less dangerous and more environmentally friendly alternative to hard chrome plating (Bolelli, 2012). Because the WC-based powders contain heavy metals such as Co and Ni (Brezinova et al., 2015; Aw and Tan, 2006; Żórawski, 2013; Sahraoui et al., 2010; Saha et al., 2011; Wood, 2010; Hulka et al., 2011; Hong et al., 2013a, b; Santana et al., 2008; Berget et al., 2007; Mati et al., 2007; Zavareh et al., 2015; Kaur et al., 2009), there is very strict logistics of powders used for coatings formation in the HVOF process. Currently, effort of materials scientists is focused on developing new powders, in which these elements in metallic matrix is eliminated and are replaced by other alloys. One of them is the powder WC-FeCrAl, called "green carbides".

The aim of the experiment was to evaluate the characteristics of the two types of coatings containing hard carbide particles in Co and also in Co-free matrix with respect to their tribological properties in atmosphere and in a corrosive environment (Brezinova et al., 2011, 2012, 2013).

\section{MATERIALS AND METHODS}

The base material for production of test samples was stainless steel AISI 316L. The test samples were of a cylindrical shape with a diameter of $25 \mathrm{~mm}$ and a length of $70 \mathrm{~mm}$. The coatings were applied to the front area of the cylinder. Before powder spraying the base material was abrasive blast cleaned using white aluminum oxide with grain size of $0.56 \mathrm{~mm}$, air pressure of $0.4 \mathrm{MPa}$, blasting angle of $90^{\circ}$ and a blasting distance of $300 \mathrm{~mm}$ (Brezinova et al., 2015; Staia et al., 2000). The coating was applied by HVOF technology using TAFA JP-5000 spraying system under spraying parameters recommended by the powder manufacturer.

Powders used:

- WC-WB-Co (60/30/10), agglomerated and sintered, grain size $+15 /-45 \mu \mathrm{m}$, used for wear and corrosion protection in molten metal (for $\mathrm{Zn}$ bath rolls in Continuous Galvanizing Lines),

- WC-FeCrAl (85/15), agglomerated and sintered, grain size $+15 /-45 \mu \mathrm{m}$, wear resistant coating with $\mathrm{Ni}$ - and Co-free metallic binder, replacement for WC-Co or WC-Ni. 
The quality and thickness of coatings were assessed on metallographic sections using light and electron microscopy. The microhardness of the coatings was evaluated also on the metallographic sections (HV 0.1, $15 \mathrm{~s}$ )

The coatings were evaluated as-sprayed and after thermal cycles. One thermal cycle consisted of heating to $600^{\circ} \mathrm{C}$, dwell time of $10 \mathrm{~min}$ in furnace, followed by natural air cooling at room temperature. The number of cycles: 5 and 10.

Adhesion of coatings was determined by pull-off test (using $2 \mathrm{~K}$ adhesive Loctite 9497) and wear resistance of coatings by pin-ondisc test (load $1.5 \mathrm{~N}$, velocity $0.02 \mathrm{~m} . \mathrm{s}^{-1}$, duration of test $60 \mathrm{~min}$, environment: atmosphere and immersion in $1 \mathrm{M} \mathrm{NaCl}$ solution, a static counterpart $\mathrm{SiC}$ ball).

\section{RESULTS AND DISCUSSION}

The thickness of the coatings was evaluated on several metallographic cross-sections. The cross-section of the coatings displayed by means of light microscopy (LM) is shown in Fig. 1 . There the thickness of the coatings can be seen.

a)

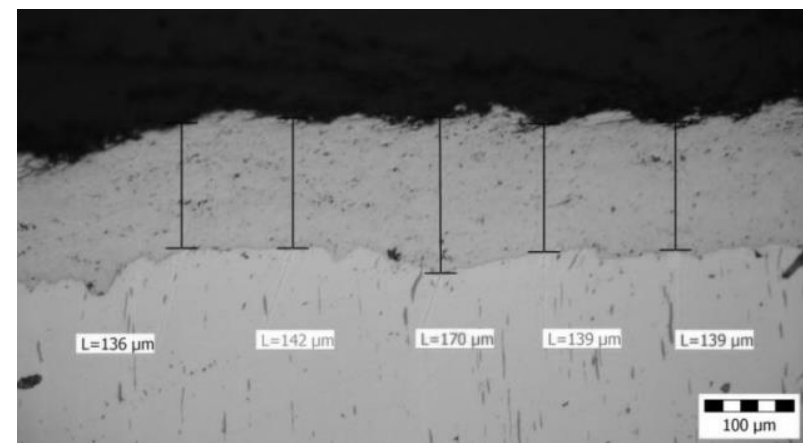

b)

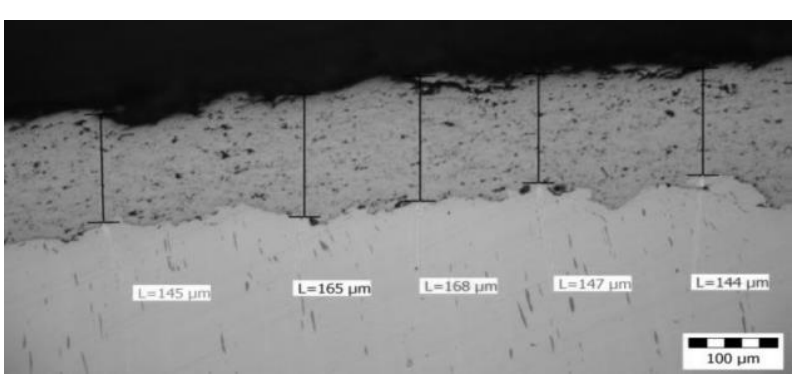

Fig. 1. Metallography section of the coatings: a) WC-WB-Co,

b) WC-FeCrAl, LM

There is is a visible interface between the substrate and the coating in Fig. 1. The interface is broken, corresponding to profile of surface after grit blasting. The coating good fills all valleys in the surface, in the interface are not present any defects. The coatings are well anchored in surface irregularities. Average coatings thickness varies from 145 to $174 \mu \mathrm{m}$.

More detailed analyses of the structure of coatings were performed using SEM. The microstructure of the coating at magnification $5000 \times$ is showed in Fig. 2.

The coating WB-WC-Co consists of two types of hard particles (WC and WB) in soft binding Co matrix which ensures the coherence of carbides. The coating WC-FeCrAl contains hard particles of WC in a matrix based on FeCrAl alloy. Results of EDX analysis of chemical composition of coatings as-sprayed and also after thermal cycles are shown in Fig. 3. a)

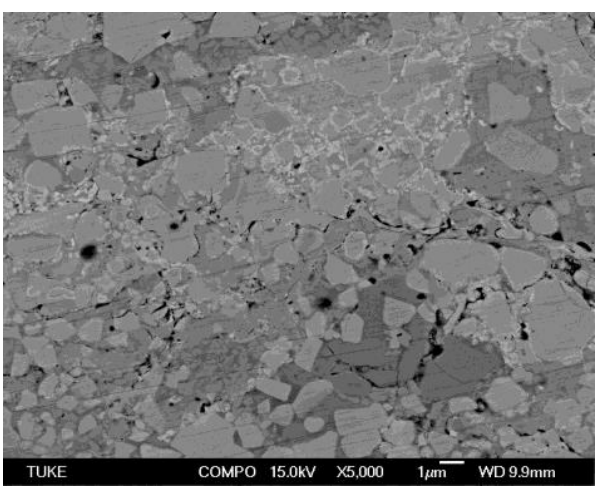

b)

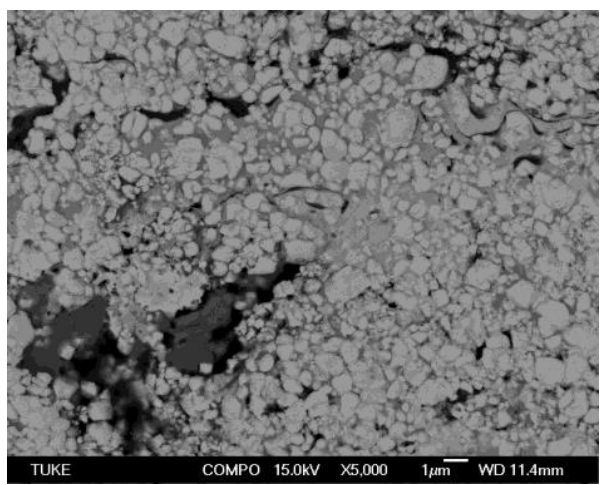

Fig. 2. SEM image of the coatings: a) WC-WB-Co, b) WC-FeCrA

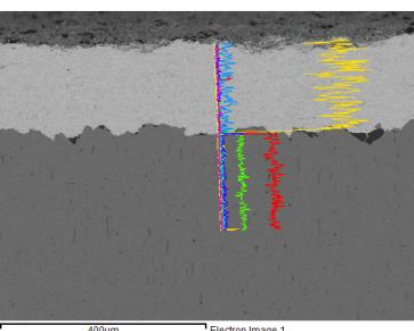

WC-WB-Co as sprayed

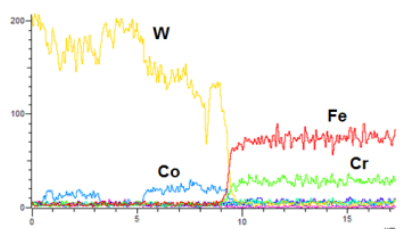

after 5 thermal cycles

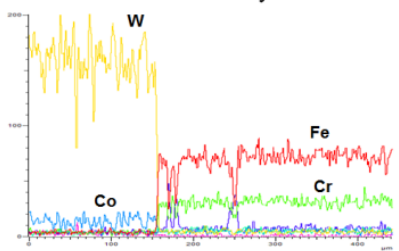

after 10 thermal cycles

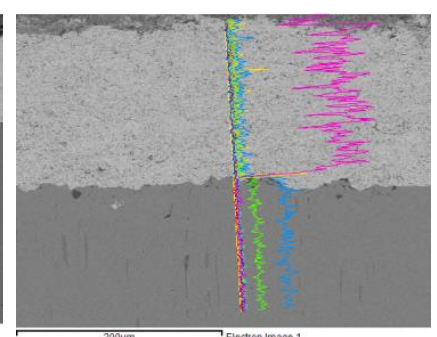

WC-FeCrAl as sprayed

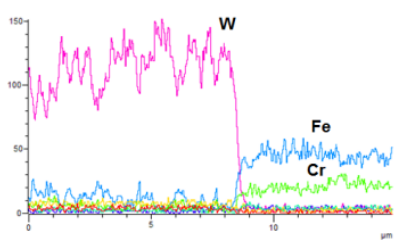

after 5 thermal cycles

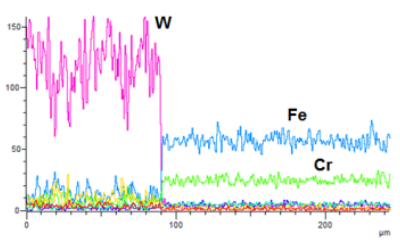

after 10 thermal cycles
Fig. 3. EDX line scan composition profiles

Results showed that there are no changes in chemical composition of the coatings caused by thermal cyclic load.

The hardness of the coating WC-WB-Co was found between 1200 and 1300 HV 0.1 and hardness of coating WC-FeCrAl between 1000 and $1100 \mathrm{HV} 0.1$. Adhesion of both coatings as sprayed, or after thermal cyclic loading exceeded the cohesive strength of the adhesive used (>50 MPa). The results of determination of thickness, hardness, and adhesion of coatings are summarized in Tab. 1. 
Tab.1. Results of the tests

\begin{tabular}{|l|c|c|c|}
\hline \multicolumn{4}{|c|}{ WC-WB-Co } \\
\hline $\begin{array}{c}\text { Number of thermal } \\
\text { cycles }\end{array}$ & $\begin{array}{c}\mathbf{0} \\
\text { (as sprayed) }\end{array}$ & $\mathbf{5}$ & $\mathbf{1 0}$ \\
\hline Thickness / $\mathbf{\mu m}$ & 145 & 151 & 160 \\
\hline Hardness HV0.1 & 1303 & 1325 & 1229 \\
\hline Adhesion / MPa & $>56$ & $>51$ & $>50$ \\
\hline \multicolumn{4}{|c|}{ WC-FeCrAl } \\
\hline Thickness / $\mathbf{~ u m}$ & 165 & 157 & 174 \\
\hline Hardness HV0.1 & 1075 & 1050 & 1069 \\
\hline Adhesion / MPa & $>50$ & $>56$ & $>54$ \\
\hline
\end{tabular}

Wear resistance of coatings as-sprayed and after the thermal cycles was evaluated by pin-on-disk test under dry friction conditions in the atmosphere and also immersed in the $\mathrm{NaCl}$ solution. The course of the friction coefficient during pin-on-disc test states Fig. 4.

a)

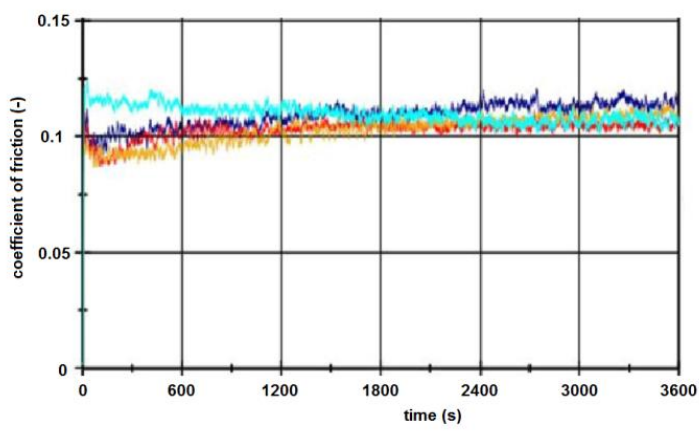

b)

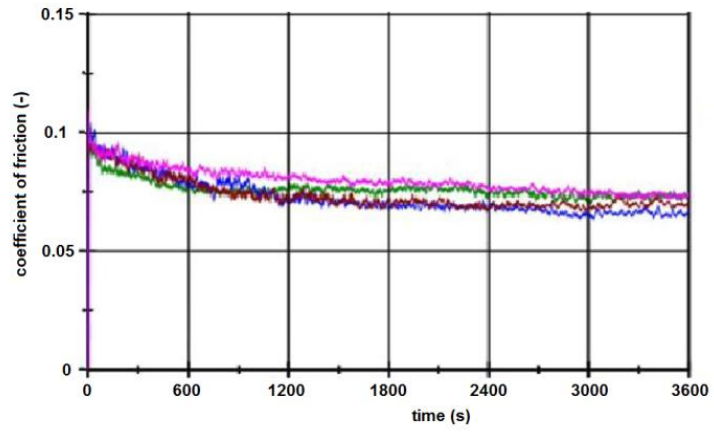

Fig. 4. Friction coefficient of the coatings after 5 and 10 thermal cycles in the atmosphere a) and in $\mathrm{NaCl}$ solution b)

Friction coefficient of the coatings in the atmosphere after the initial start-up became stabilized at a value of 0.1 , and immersed in $\mathrm{NaCl}$ solution was stabilized below 0.1. During adhesive friction test in corrosive solution, the coefficient of friction stabilized at a lower value than in atmosphere.

The appearance of the coatings surface in wear track and out of wear track is shown in Fig. 5 .

Weight loss of coatings after pin-on-disk test was minimal so could not be determined although the resolution of the balance was 10 to the negative $4^{\text {th }}$ power [g], as confirmed also appearance of wear track. Surface of coatings in wear track and out of wear the track is almost identical, they are visible no signs of particles removed from coating material. Conversely, on the static counterpart was found visible loss of material, Fig. 6.
Material loss of each static counterpart is the same, judging by size of wear area - there are no differences between friction pairs as sprayed and after thermal cycling, as well as no differences between tests in the atmosphere and $\mathrm{NaCl}$ solution.
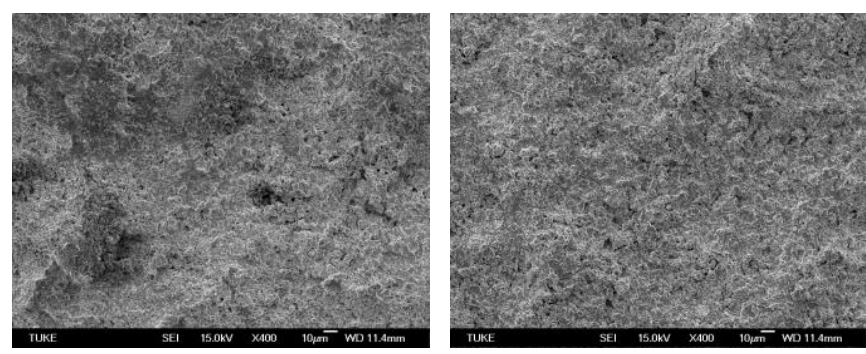

surface of coatings in wear track

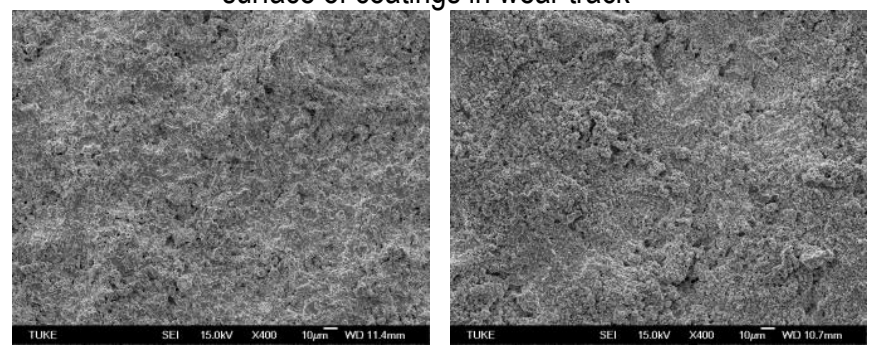

surface of coatings out of wear track WC-WB-Co

WC-FeCrAl

Fig. 5. Surface of the coatings in wear track and out of wear track
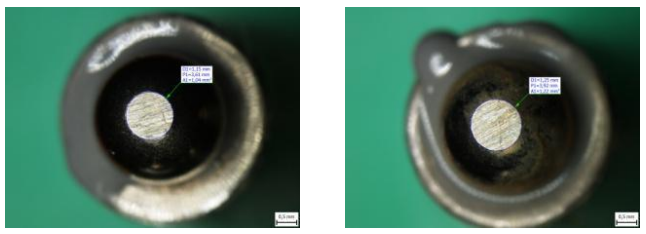

after 5 thermal cycles

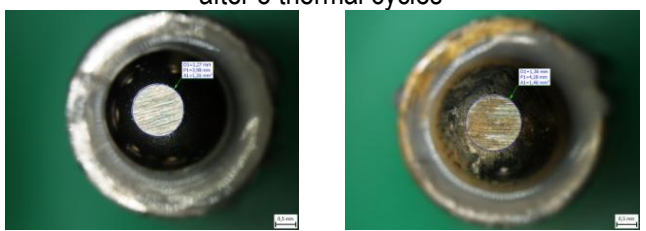

after 10 thermal cycles after contact with WC-WB-Co

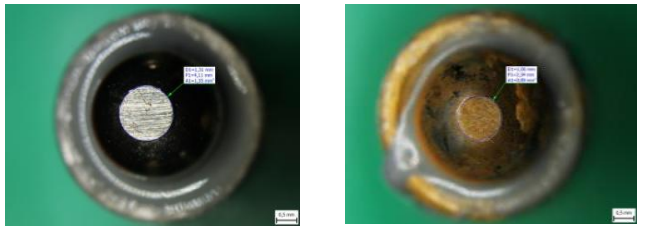

after 5 thermal cycles

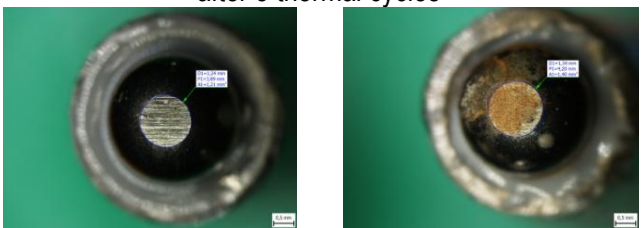

$$
\begin{aligned}
& \text { after } 10 \text { thermal cycles } \\
& \text { atmosphere } \\
& \text { after contact with WC-FeCrAl }
\end{aligned}
$$

Fig. 6. Appearance of static balls

On the surface of static balls used in $\mathrm{NaCl}$ solution corrosion products are present. 


\section{RESULTS}

Both coatings exhibited comparable properties as for thickness (140-170 $\mu \mathrm{m})$, hardness (1300 and $1050 \mathrm{HV} 0.1$ ), adhesion (> $50 \mathrm{MPa}$ ), and also in terms of adhesive wear resistance (nonmeasurable weight loss, low friction coefficient: 0.1 in the atmosphere and also in $\mathrm{NaCl}$ solution). It can be concluded that "green carbides" coating is environmentally more friendly replacement for coatings containing $\mathrm{Co}$ and $\mathrm{Ni}$ without reducing the performance of the coating.

\section{REFERENCES}

1. Aw P.K., Tan B.H. (2006), Study of microstructure, phase and microhardness distribution of HVOF sprayed multi-modal structured and conventional WC-17Co coatings, Journal of Materials Processing Technology, 174(1-3), 305-311.

2. Berget J., Rogne T., Bardal E. (2007), Erosion-corrosion properties of different WC-Co-Cr coatings deposited by the HVOF processinfluence of metallic matrix composition and spray powder size distribution, Surface and Coatings Technology, 201(18), 7619-7625.

3. Bolelli G., Börner T., Bozza F., Cannillo V., Cirillo G., Lusvarghi L. (2012), Cermet coatings with Fe-based matrix as alternative to WC-CoCr: Mechanical and tribological behaviours, Surface and Coatings Technology, 206(19-20), 4079-4094.

4. Brezinová J., Guzanová A. (2012), Possibilities of utilization high velocity oxygen fuel (HVOF) coatings in conditions of thermal cyclic loading, Metalurgija, 51(2), 211-215.

5. Brezinová J., Guzanová A., Draganovská D. (2015a), Abrasive blast cleaning and its application, 1st. Ed., Pfaffikon: Trans Tech Publications

6. Brezinová J., Guzanová A., Draganovská D., Bronček J. (2015b), Quality evaluation of HVOF coatings on the basis of WC-Co in tribocorrosive conditions, Materials Science Forum, 811, 63-66.

7. Brezinová J., Guzanová A., Draganovská D., Egri M. (2013), Assessment tribological properties of coatings applied by HVOF technology, Acta Mechanica et Automatica, 7(3), 135-139.

8. Brezinová J., Guzanová A., Egri M. (2012), Change in properties of HVOF coatings under conditions of thermal cyclic loading, Chemické listy, 106(S3), 383-386.

9. Brezinová J., Guzanová A., Egri M., Malejčík J. (2011), Evaluation of thermal sprayed coatings properties in terms of erosive wear, Chemické listy: special issue, 105(17), 775-776.

10. Hong S., Wu Y., Wang Q., Ying G., Li G., Gao W., Wang B., Guo W. (2013a), Microstructure and cavitation-silt erosion behavior of high-velocity oxygen-fuel (HVOF) sprayed $\mathrm{Cr} 3 \mathrm{C} 2-\mathrm{NiCr}$ coating, Surface and Coatings Technology, 225, 85-91.
11. Hong S., Wu Y., Zheng Y., Wang B., Gao W., Lin J. (2013b), Microstructure and electrochemical properties of nanostructured WC-10Co-4Cr coating prepared by HVOF spraying, Surface and Coatings Technology, 235, 582-588.

12. Hulka I., Uţu D., Şerban V.A. (2011), Micro-scale sliding wear behavior of HVOF sprayed WC-Co(Cr), Annals of Faculty Engineering Hunedoara - International Journal of Engineering, 9(2), 61-64.

13. Kaur M., Singh H., Prakash S. (2009), High-Temperature Corrosion Studies of HVOF-Sprayed Cr3C2-NiCr Coating on SAE-347H boiler steel, Journal of Thermal Spray Technology, 18(4), 619-632.

14. Maiti A.K., Mukhopadhyay N., Raman R. (2007), Effect of adding WC powder to the feedstock of WC-Co-Cr based HVOF coating and its impact on erosion and abrasion resistance, Surface and Coatings Technology, 201(18), 7781-7788.

15. Saha G.C., Khan T.I., Zhang G.A. (2011), Erosion-corrosion resistance of microcrystalline and near-nanocrystalline WC-17Co high velocity oxy-fuel thermal spray coatings, Corrosion Science, 53(6), 2106-2114.

16. Sahraoui T., Guessasma S., Jeridane M. A., Hadji M. (2010), HVOF sprayed WC-Co coatings: Microstructure, mechanical properties and friction moment prediction, Materials and Design, 31(3), 1431 - 1437

17. Santana Y.Y., La Barbera-Sosa J.G., Caro J., Puchi-Cabrera E.S., Staia M.H. (2008), Mechanical properties and microstructure of WC10Co-4Cr and WC-12Co thermal spray coatings deposited by HVOF, Surface Engineering, 24(5), 374-382.

18. Staia M.H., Ramos E., Carrasquero A., Roman A., Lesage J., Chicot D., Mesmacque G. (2000), Effect of substrate roughness induced by gritblasting upon adhesion of WC- $17 \%$ Co thermal sprayed coatings, Thin Solid Films, 377-378, 657-664.

19. Wood R.J.K. (2010), Tribology of thermal sprayed WC-Co coatings, International Journal of Refractory Metals and Hard Materials, 28(1), 82-94.

20. Zavareh M.A., Sarhan A.A.D.M., Razak B.B.A., Basirun W.J. (2015), The tribological and electrochemical behavior of HVOFsprayed $\mathrm{Cr} 3 \mathrm{C} 2-\mathrm{NiCr}$ ceramic coating on carbon steel, Ceramics International, 41(4), 5387-5396.

21. Žórawski W. (2013), The microstructure and tribological properties of liquid-fuel HVOF sprayed nanostructured WC-12Co coatings, Surface and Coatings Technology, 220, 276-281.

"This contribution is the result of the project implementation: „Unique equipment for evaluation of tribocorrosion properties of the mechanical parts surfaces" (ITMS: 26220220048) supported by the Research \& Development Operational Programme funded by the ERDF and project VEGA No. 1/0600/13. This work was supported by the Slovak Research and Development Agency under the contract No. SK-UA-2013-0013. 